\title{
PARP Inhibitor AZD2461
}

National Cancer Institute

\section{Source}

National Cancer Institute. PARP Inhibitor AZD2461. NCI Thesaurus. Code C95201.

An orally bioavailable inhibitor of the nuclear enzyme poly(ADP-ribose) polymerase (PARP) with potential antineoplastic activity. PARP inhibitor AZD2461 selectively binds to PARP and prevents PARP-mediated DNA repair of single strand DNA breaks via the baseexcision repair pathway. This enhances the accumulation of DNA strand breaks and promotes genomic instability and eventually leads to apoptosis. PARP catalyzes posttranslational ADP-ribosylation of nuclear proteins that signal and recruit other proteins to repair damaged DNA and is activated by single-strand DNA breaks. 